\title{
Evaluation of Vulnerability of the Underground Aquifer of the Gharb Plain with the Help of Gis and Drastic Method (Nw of Morocco)
}

\author{
El Mahmouhi Nezha, \\ El Wartiti Mohamed, \\ Azelmad Rajae, \\ Sadki Ridouane \\ Berred Sanae,
}

University of Mohamed V in Rabat, Laboratory of applied geology of the faculty of sciences, Morocco

doi: 10.19044/esj.2016.v12n36p387 URL:http://dx.doi.org/10.19044/esj.2016.v12n36p387

\begin{abstract}
Water is a rare resource and badly distributed in Morocco. In spite of the sectorial politics enterprise by persons responsible during more than 50 years in order to control these resources, the problem of the rarity and the deterioration of the water quality always imposes itself. The aquifer complex of the Gharb constitutes an exceptional water reserve for Morocco but these resources are threatened by different types of pollution (agricultural, urban and industrial) according to the economic progress and the relatively fast demographic growth. In this sense and for a better management and the safeguard of water resources of the deep aquifer of the Gharb that we elaborated a map of vulnerability with the help of the DRASTIC method based on seven parameters, controlling water pollution process, seize under shape of data base managed by a Geographic Information System (GIS). The obtained vulnerability map constitutes an easily usable tool for the identification of risk zones where protection measures are necessary, for a better management of the important water resources of the region and also for the immediate intervention in case of accidental pollution.
\end{abstract}

Keywords: Water resources, Gharb, vulnerability, Morocco, DRASTIC, Geographic Information System (GIS).

\section{Introduction}

The multi-layered aquifer complex of the Gharb constitutes one of the potential zones of water in Morocco. It is estimated of 20 billion m3. A 
volume of $137.109 \mathrm{~m}^{3}$ is removed annually for water consumption in the region (DRPE, 1996). In this agricultural, water necessities increase due to population growth, intensification and modernisation of agriculture and industrial development (Cherifian company of petrol, Moroccan of carton and papers). That is why causes and aspects of pollution vary and multiply, and this demands a protection of water resources and their territory. One of the possible tools for this protection is the establishment of a vulnerability map for the pollution of profound aquifer of Gharb with the help of drastic method of Aller \& al. (1985). The formation of such map demands climatic , geological, hydrogeological as well the achievement of a sampling water campaign and underground water analyses Digitalization, data entry and its treatment are achieved via using GIS (Arc view and Map info).

The different lithologies occurring in the Sebou basin give rise to several distinct hydrogeological sectors (Fig.1). In the Middle Atlas the Jurassic sequence has a thickness of 250-300 m (Essahlaoui, 2000) and represent an important aquifer in the area, the fractured and karstified dominant carbonate rocks allowing water infiltration at depth; the phreatic level may vary depending on the morphology, structural features and precipitations.

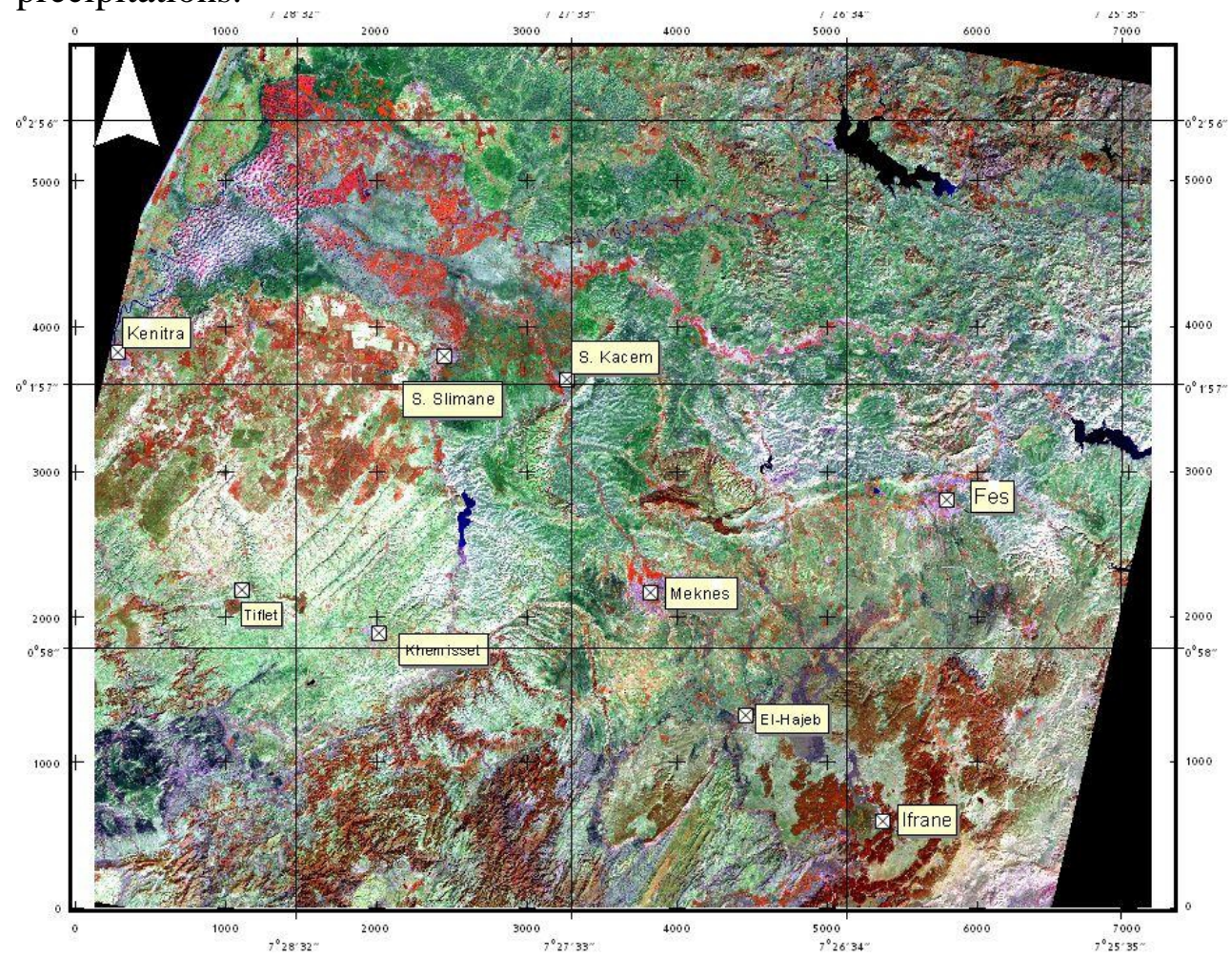

Fig.1: Satellite picture showing the various areas of the water shed of Sebou valley 
We can see the contributions of drawn additional information starting from the spatial imaging to high light the conjugation enters the groundwater, soil, agriculture and installation territorial.

In the Fes-Meknes plateaux, it is possible to distinguish several reservoirs; the water-table hosted in sand, conglomerate and lacustrine limestone is unconfined, but locally, a multi-layer aquifer occurs due to intercalated marl and clay levels especially in Fes sector (Chamayou et al., 1975). Recharge to the multi-layer aquifer is rainfall and by groundwater from adjacent deep or shallow aquifers. Faults trending NE-SW divide those aquifers into separate blocks.

During the last decades, the Gharb plain has witnessed a population booming, a cultural intensification and an industrial development. In this Moroccan region, so as to meet the increasing needs for water, groundwater constitutes the major resource for every use. Anterior works in the hydrogeological basin of the Gharb bear witness of variation of water facies. To understand this variation, we should take into account the natural processes, in relation to the lithologic diversity in the basin and the human impact resulting from the socio-economic activity. These factors contribute to the degradation of the water quality of the aquifer complex in this semiarid region of Morocco. This study constitutes a geochemical test of ground water, an evidence of the human impact on the water chemistry.

\section{Geographical and geological map}

Gharb plain is situated in the coastal margin of Atlantic north of Morocco (Fig 2).

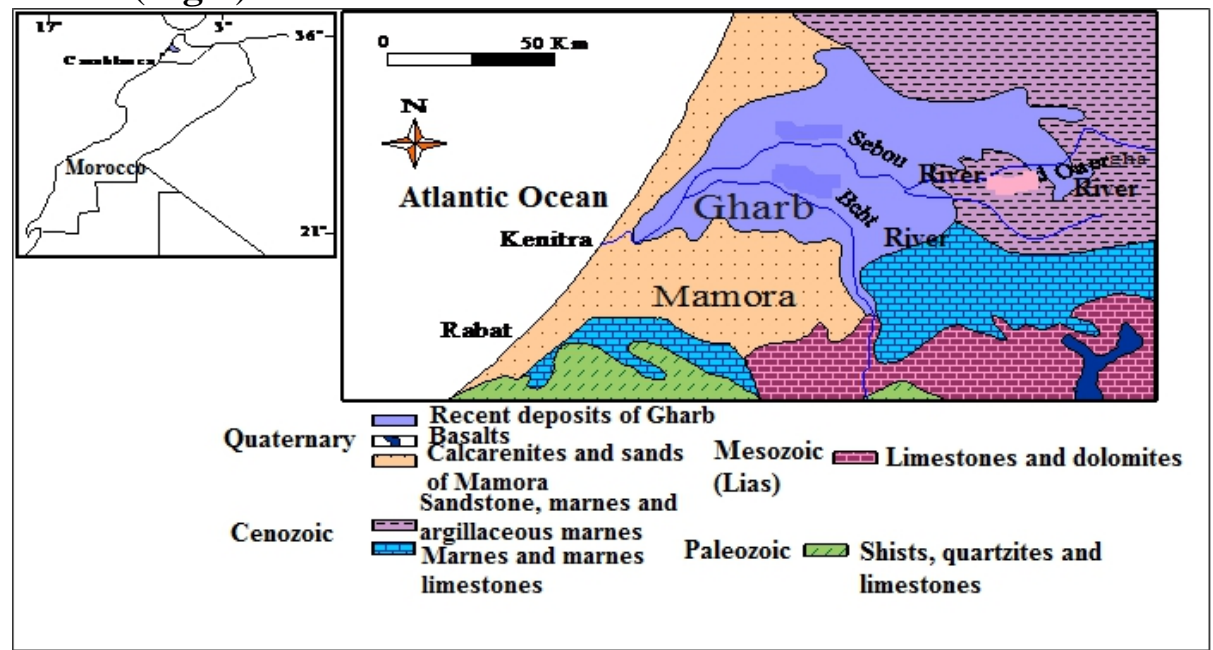

Fig. 2: Situation map of the geology of Gharb plain and its borders

Its surface is $4000 \mathrm{~km}$ which do not exceed $50 \mathrm{~m}$. This region (Gharb), with an oceanic influence, has a Mediterranean - type climate. The area 
records annual average rainfall of $500 \mathrm{~mm}$, with a gradient which decreases from the east to the west. The medium tempereture increases going from the coast $\left(23^{\circ} \mathrm{C}\right)$ towards the inner basin $\left(35^{\circ} \mathrm{C}\right)$ which demonstrate the effect of continentality. The hydrographic network is represented by one of the principal rivers of the kingdom: Sebou river and its tributaries, Ouerrha, Beht, Rdom and Tiflet (Fig. 3).

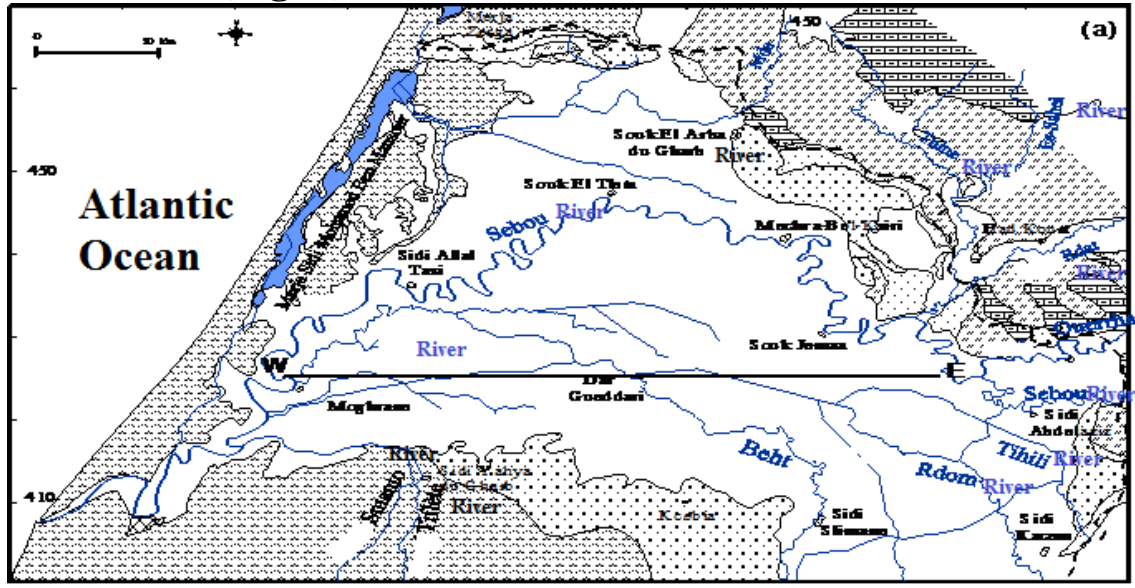

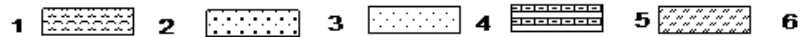

1. sandstone and dune sands; 2 . sandstone and gravel; 3 . sands and sandstone; 4 . marnes and marno-limestones; 5 . blue marnes; 6. clays and silty clays fine silts and silty -argillaceous sands

Fig.3 : Map of the geological surface of Gharb's plain and hydrographical network.

This complex hydrophic network presents a risk of frequent floods due to irregular seasonal rainfall. The stratigraphic column of the Gharb is composed by a substratum of palaeozoic age which incorporates sedimentary and metamorphic rocks (Fig. 3) : schist, quartzite and limestone (Michard, 1976), overcame by red, clayey deposits of Trias and by dolomites and dolomitic limestones of Jurassic and Cretaceous period.The Miocene which constitutes the impermeable flooring of Gharb's Deep groundwater (Michard, 1976), is formed by blue marls. In the Pliocene the sedimentation has a double origins : the first transgressions on the current coastal gave birth to a coastal sedimentation represented by sandstone and limestone. This formation of the coastal,which can be up to $200 \mathrm{~m}$ thick constitutes the aquiferous reservoir of major. (Combe, 1975) Upstream towards the east, continental sediments accumulate which alternate between rough and fine according to the rainfall and violence of erosion on the continent during the period of its creation (Cirac, 1987).

The trangeressions of quaternary were represented again by calcarenite of the coast and by a carbonate detrital sedimentation to clay intercalations. Across this sedimentary succession, the aquifers are installed during miocen transport. These aquifers are essentially formed by turbiditic marine clays and by evaporates of Trias which are interbedded in the bluish 
and gypsiferous marls. The surface area coverage of Gharb is characterized by an extension of favourable clay and sandy soils to a wide range of cereal crops.

\section{Hydrogeology}

The deep aquifer of Ghar, which is multi-layered in nature and whose surrounding is a plioquaternary age, circulates primarily of side is the in coarse level of gravel and pebble (Fig. 4) having a permeability which ranges between $1.10^{-3} \mathrm{~m} / \mathrm{s}$ and $4.10^{-3} \mathrm{~m} / \mathrm{s}$ (DRPE, 1994).

In the west and in the south, the lythology is represented by sandtones and calcareous sands with clay Intercalations whose permeability is included between $10^{-5} \mathrm{~m} / \mathrm{s}$ and $5.10^{-5} \mathrm{~m} / \mathrm{s}$ (DRPE, 1989).

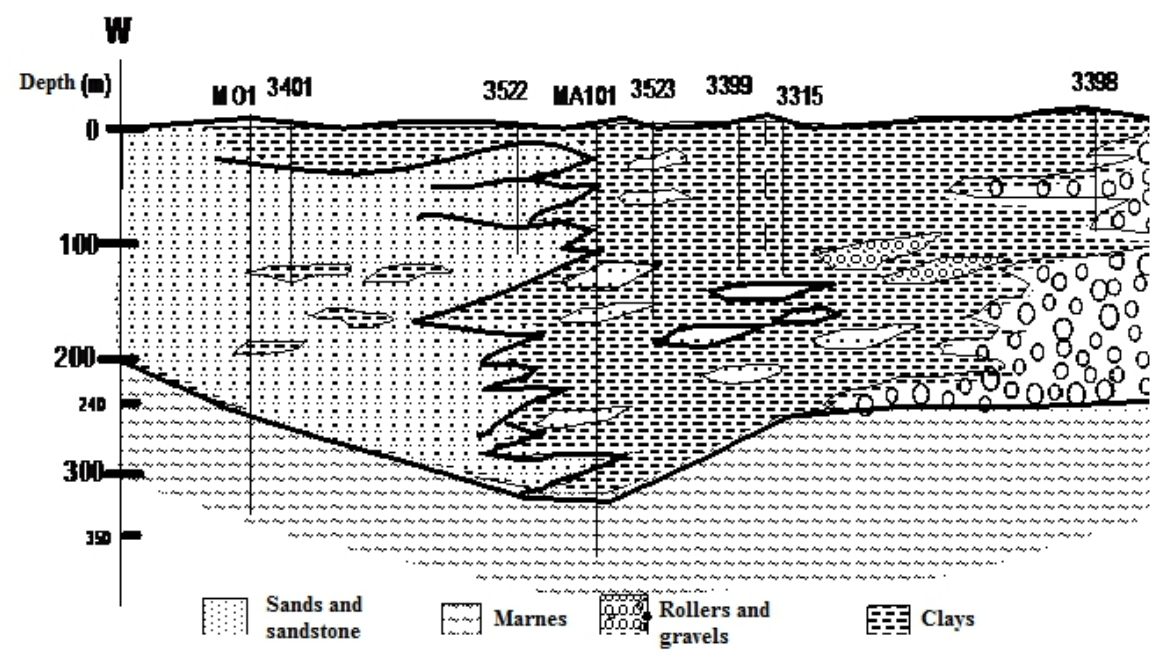

Fig. 4 : Morphology of Gharb's aquifer using E-W CUT

This aquifer presents a hydrogeological interest to the regional scale characterized by important recharge.

\section{Socio-economic aspects}

Since 1920, Different managements were undertaken in plain which is recorded as one of the major zones of the kingdom's activities however, the industrial and the agricultural human activities contribute to vulnerability of the aquifer. It is the cause of multiple and high levels of pollutions which give rise to uneven consequences (El Mahmouhi, 2004).

\section{The social sector}

According to the census of 1994, population within the perimeter of the Gharb contains 1.243.787 inhabitants of which 691.706 are in the rural areas, that is to say $56 \%$ of the whole Gharb population. Between 1982 and 
1994, the average growth rate rose to $3 \%$. This rate more important than the national average which is $2,06 \%$ (RGPH, 1994). This population growth, especially in the rural areas which are deprived of basic sanitation, frequently lead to an intense pollution of underground water due to nitrogen deposition compounds.

\section{The economic sector}

Taking advantage of privileged geographical location, fertile soil and important hydric resources, the gharb plain contributes to the economic growth of the kingdom. The region development is solely based on agriculture. The major types of crops are cereals, especially rice (total national production), sugar cane (65\% of the national production), sugar beet ( $22 \%$ of the national production) and oleaginous fruits $(48 \%$ of the national production). The industry in this zone is represented sugar refinery, alcohol distillery, paper mill and petrol refinery. The uncontrolled waste is discharged in the Sebou river or in the uncontrolled garbage dumps usually lying on the permeable grounds. The polluting substances existing in the Sebou river are diverse. In general, they constitute mineral and organic substances in suspension, heavy metals and phenol or cyanide (DGH, 1999), hydrocarbons as well the agricultural pollutants such as fertilizers, pesticides and phytosanitary products.

\section{Working methodology}

The necessity to know the degree of underground water risk in Gharb plain led to the creation of a vulnerability map of pollution. The necessary data for the realization of a vulnerability map by the drastic method was collected from the concerned organizations : General Direction of Hydraulic ( G D H ), Regional direction of Hydraulic of Sebou in Fes (RDH), Regional office of Gharb's agriculture development( R O G A D ) and water service in Kenitra .

This data was directly achieved from the work done in the field research. The employed methods for the evaluation of water vulnerability are diverse .However, the drastic method remains the most used one in the international scale. It constitutes an empirical model developed by EPA (Environmental Protection Agency) in 1987 for the aim of evaluating potential pollution of underground waters (Aller \& al., 1985).

The seven physical and hydrological parameters from which model's name derives are: Water depth ( D ), the recharge ( R ), aquifer nature ( A ), soil ( S ), Topography ( $\mathrm{T}$ ), the impact of the unsaturated zone ( I ) and the hydraulic conductivity ( $\mathrm{C}$ ). The relative weight for each parameter is variable from 1 to 5 . The most significant parameters are having a weight of 5 , The least significant ones have a weight of 1 . Score weighting was done 
depending on the importance of each parameter of the drastic method. The drastic hint matches with the sum of weights products by the estimated points for each parameter. A hint which results from this equation (Id = Dr Dw + $\mathrm{Rr} \mathrm{Rw}+\mathrm{Ar} \mathrm{Aw}+\mathrm{Sr} \mathrm{Sw}+\mathrm{Tr} \mathrm{Tw}+\mathrm{Ir} \mathrm{Iw}+\mathrm{Cr} \mathrm{Cw}$ avec hi = hint DRASTIC ; $\mathrm{r}=$ note and $\mathrm{w}=$ weight) is designed as an indication of geographical zone which is susceptible to underground water contamination. The database is digitalized on the digitalization label with the help Info map software program. The digital data were entered in the excel database. After this step, the compilation of thematic maps and their treatment were done by means of geographical information system. Water sampling in 2001 and 2002 and analyses in laboratory were done with collaboration with chemistry laboratory of water university of Cagliari (Italy) Nitrate content in the underground waters of Gharb is detected by means of Ionic liquid chromatography.

\section{Establishement of thematic maps}

The creation of vulnerability map requires the combination of thematic maps of seven parameters of the drastic method with a view to compensating the special gaps of the pre-existing data.

\section{A map of water depths (D)}

This map (Fig.5) was formulated according to the difference between Piezometric map of 1/50 000 established by (Combe, 1967), representing the aquifer in its balanced, and the map related to the topography of the plain of $1 / 50000$. First, the maps are georeferenced and digitalized on Info map. The calculation of the difference between the two values, piezometric and topographical at the level of mesh is realized with the help of software Arc view.

The drastic notation is attributed to the following parameter: the Aquifer depth. The weakest point is related to water depth superior to $30 \mathrm{~m}$. The highest points are frequent in the coastal zone and the south of the basin are related to inferior depths of 1,5m (Fig. 4). 


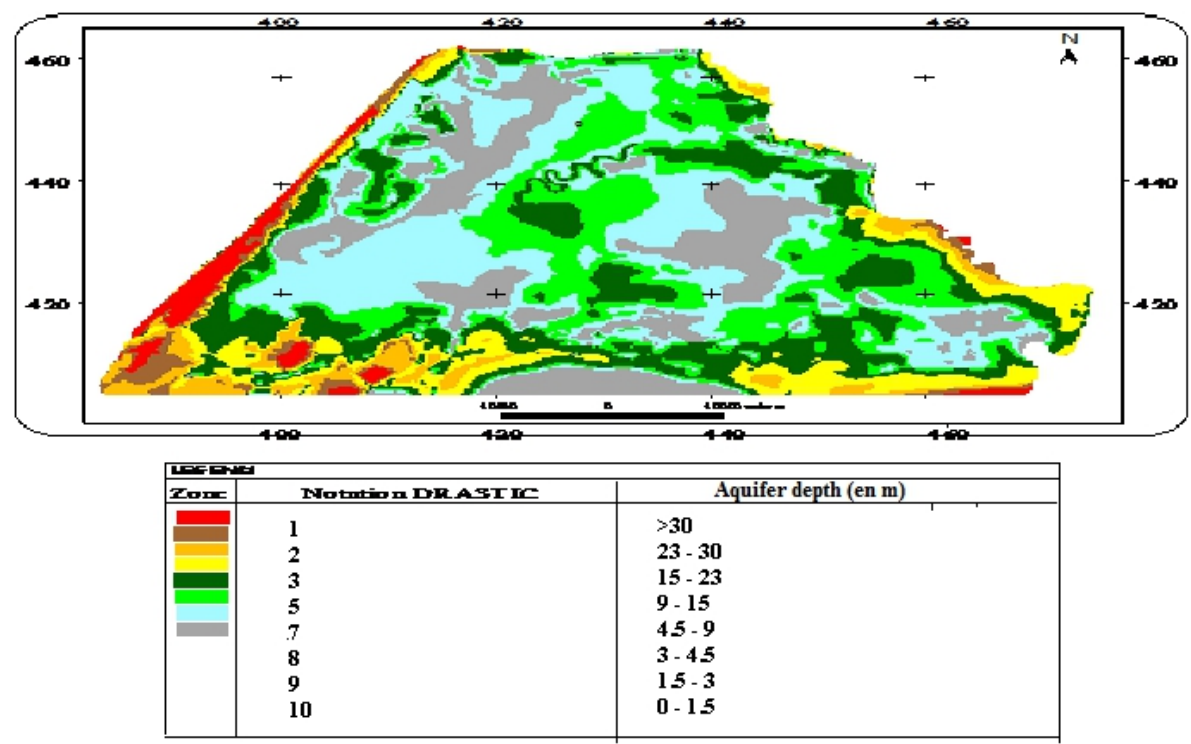

Fig.5 : Map of depths repartition -DRASTIC NOTATION -

\section{Recharge map (R)}

This recharge map is done relying on a study accomplished by DGH (1996). For each interval of recharge, we have assigned the following points, the drastic method. The highest points are related to a superior recharge of $15 \%$ and are noted at the level of basin borders. The weakest values are recorded in the center (Fig. 6).

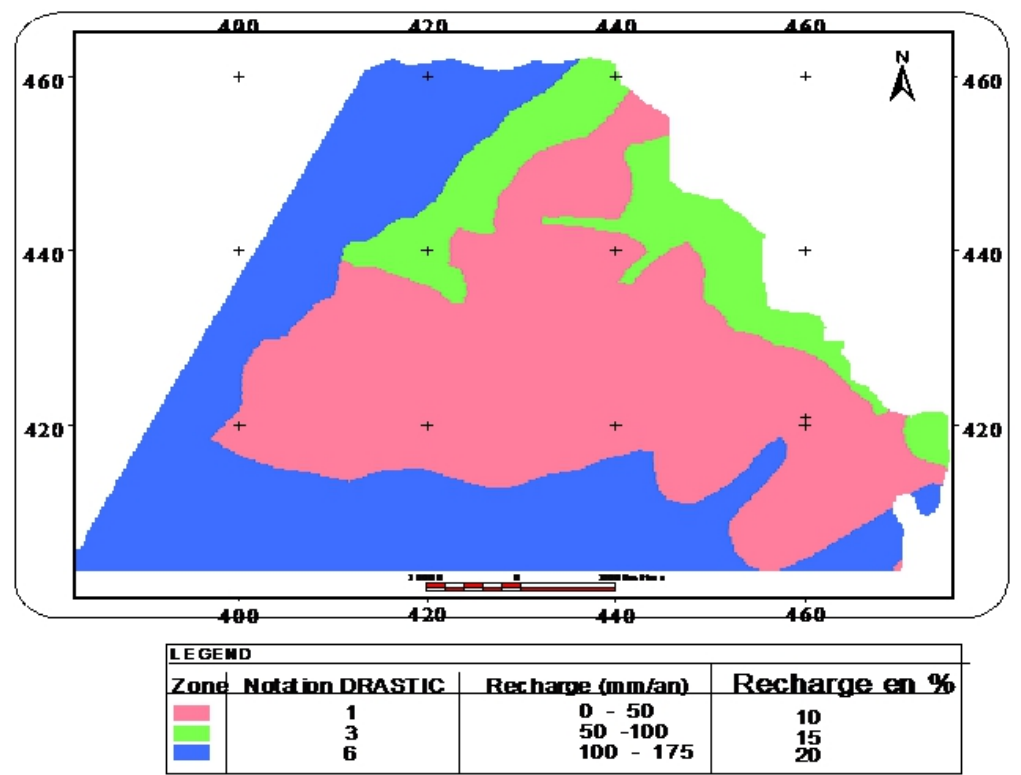

Fig.6 : Recharge map of Gharb's aquifer - DRASTIC NOTATION - 


\section{Map of geological features of the saturated zone (A)}

This map was digitalized relying on a map of geological features of the aquifer 1/50 000 (Combe, 1967) and completed by drillings collected by DGH. This shows heterogeneity of geological features of saturated zone of Gharb. So, we have distinguished a permeable formation made by sandstones, sands, pebbles and gravels and impermeable formation which contains clay, loamy clay stretching, especially in the center of the plain and in some depressions of the coastal zone. For each lithology, we have assigned the following classes to the drastic notation, or the highest points are assigned to the most permeable formations. The lowest values are assigned to impermeable formations (Fig. 7).

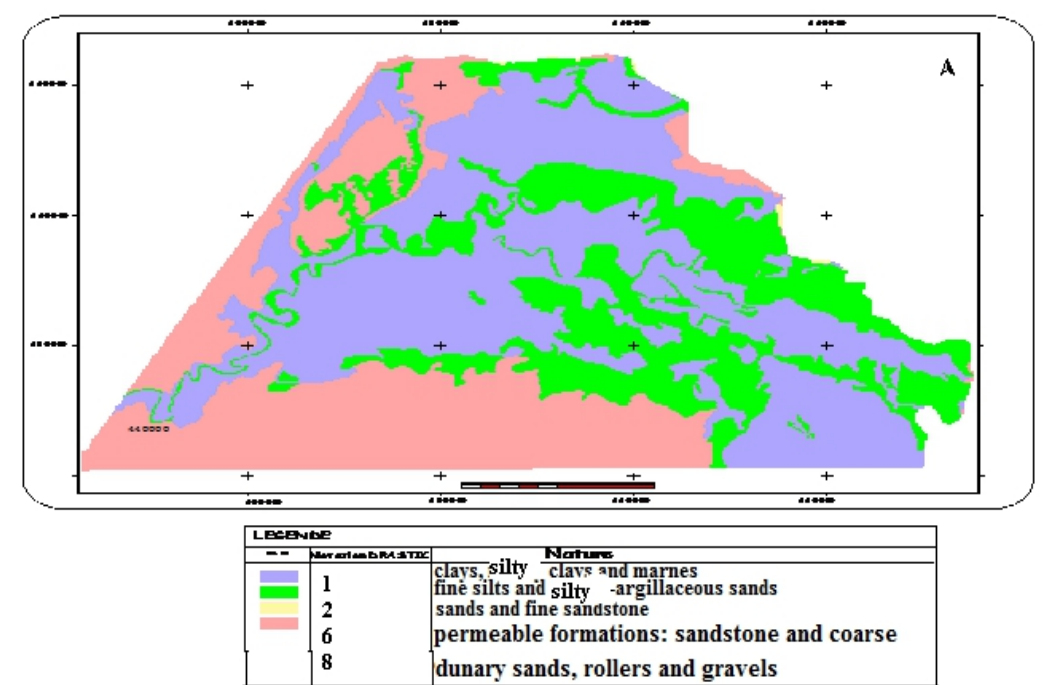

Fig.7 : Repartition map of geological features of the unsaturated zone of the Gharb's aquifer -DRASTIC NOTATION -

\section{Soils map (S)}

Concerning the formation of soils map we have conducted a digitalization info map of pedological perimeter of Gharb (Sebou project) created by ORMVAG. So, the realized map examination permits to distinguish the following soils (Fig. 8) 


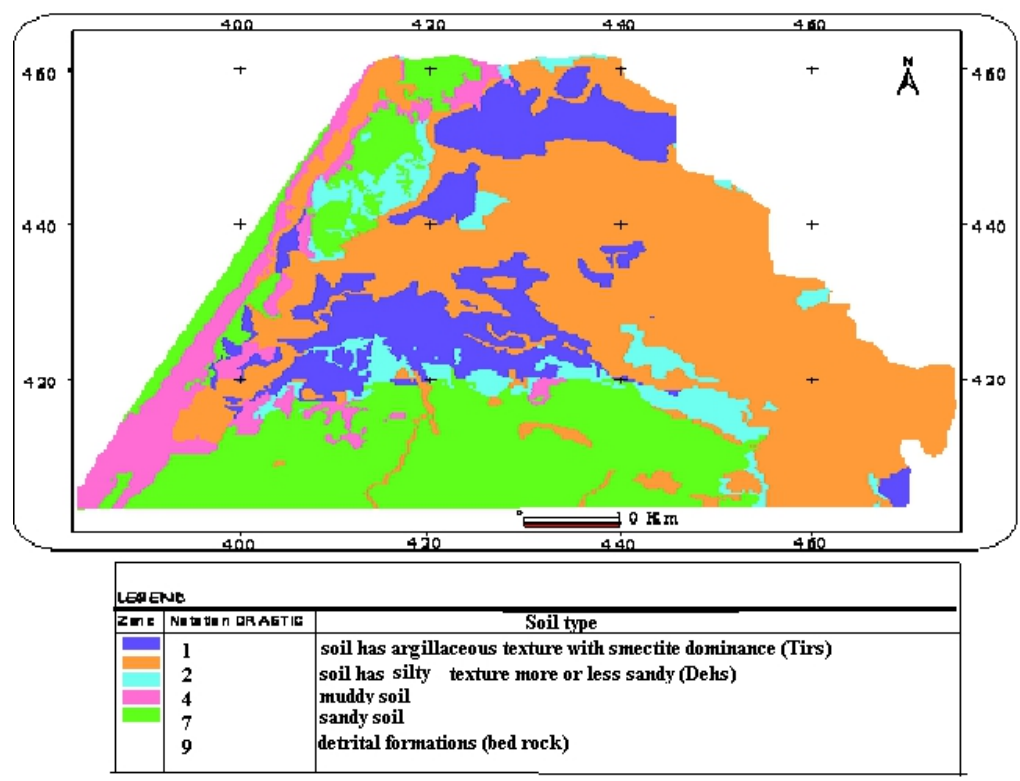

Fig.8 : Map of soils textures of Gharb's plain - DRASTIC NOTATION -

- Impermeable soils with clay textures and smectic dominance.

- $\quad$ Permeable soils with a loamy and sand texture.

- $\quad$ Permeable sandy soils.

\section{Repartition map of slopes ( $T$ )}

The formation of this map was done relying on topographical maps of $1 / 50000$ completed by punctual data exists of field and drillings files collected from the concerned directions (Fig. 9).

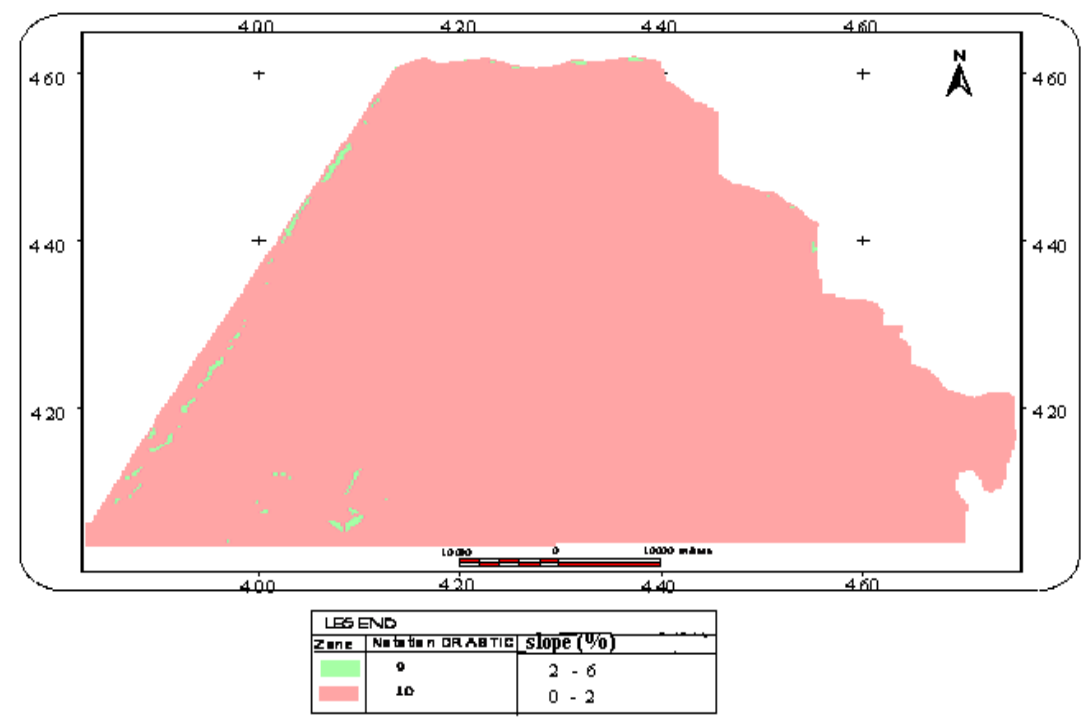

Fig.9: Repartition map of slopes -DRASTIC NOTATION - 
The slopes repartition is generally homogeneous on the whole perimeter except the borders where we note the presence of some hills whose slope doesn't exceed $14 \%$.

The inferior slopes of $2 \%$ are the dominant ones, favouring the infiltration of eventual pollutants towards the aquifer.

\section{Features map of the unsaturated zone (I)}

This map is accomplished relying on the exploitation of 600 water points disposing geographical cross-sections. The analysis of different points is obviously a contrast of thickness and lithology of the unnsaturated zone important and the lithology is semi-permeable, which consequently has a lateness of pollutants propagation towards the aquifer of their trapping by clays. After distinguishing the different features we assigned for each type a point. The highest points are assigned to permeable stretching formations on the basin borders. The underground water situated under the strong thickness are supposed to be the shelter of direct immediate contaminations. So, we assigned them the weakest points (Fig. 10).

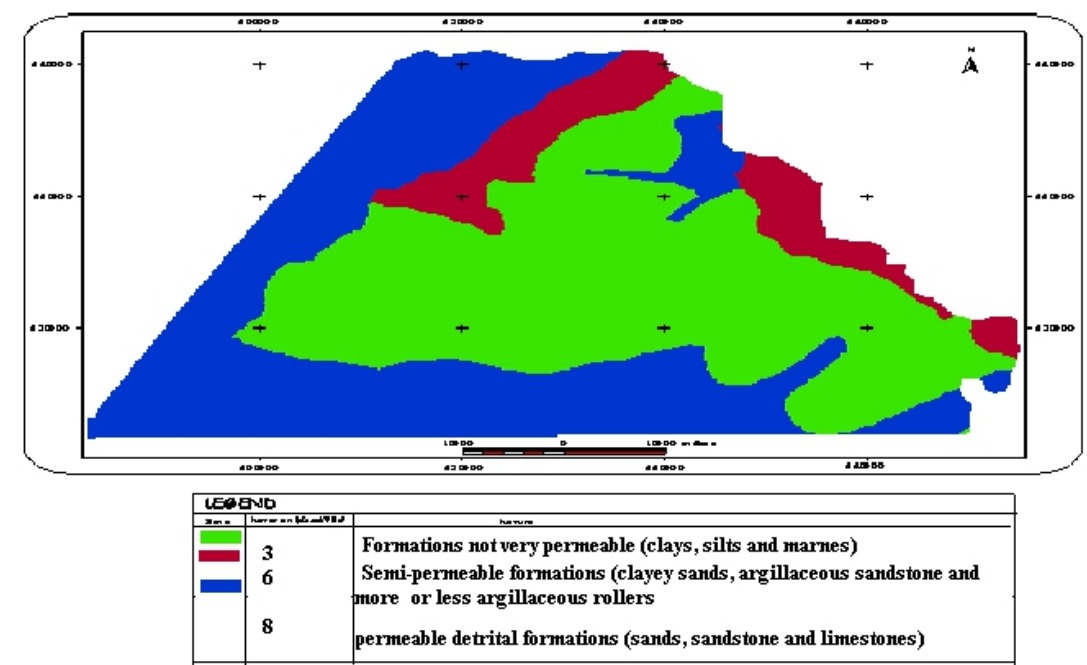

Fig.10: Repartition map of geological features of the unsaturated zone of Gharb's aquifer DRASTIC NOTATION -

\section{Map of the permeability of the aquifer (C)}

Permeability map of the aquifer was digitalized in info map relying on a permeability map accomplished by (Combe, 1968) of 1/50 000, after its actualization with the help of repartition map of permeability exists of blockage in the permanent regime of the deep aquifer (DGH, 1997).

The highest points are localized in the southern coastal zone, whereas the lowest points are frequent towards the basin (Fig. 11). 


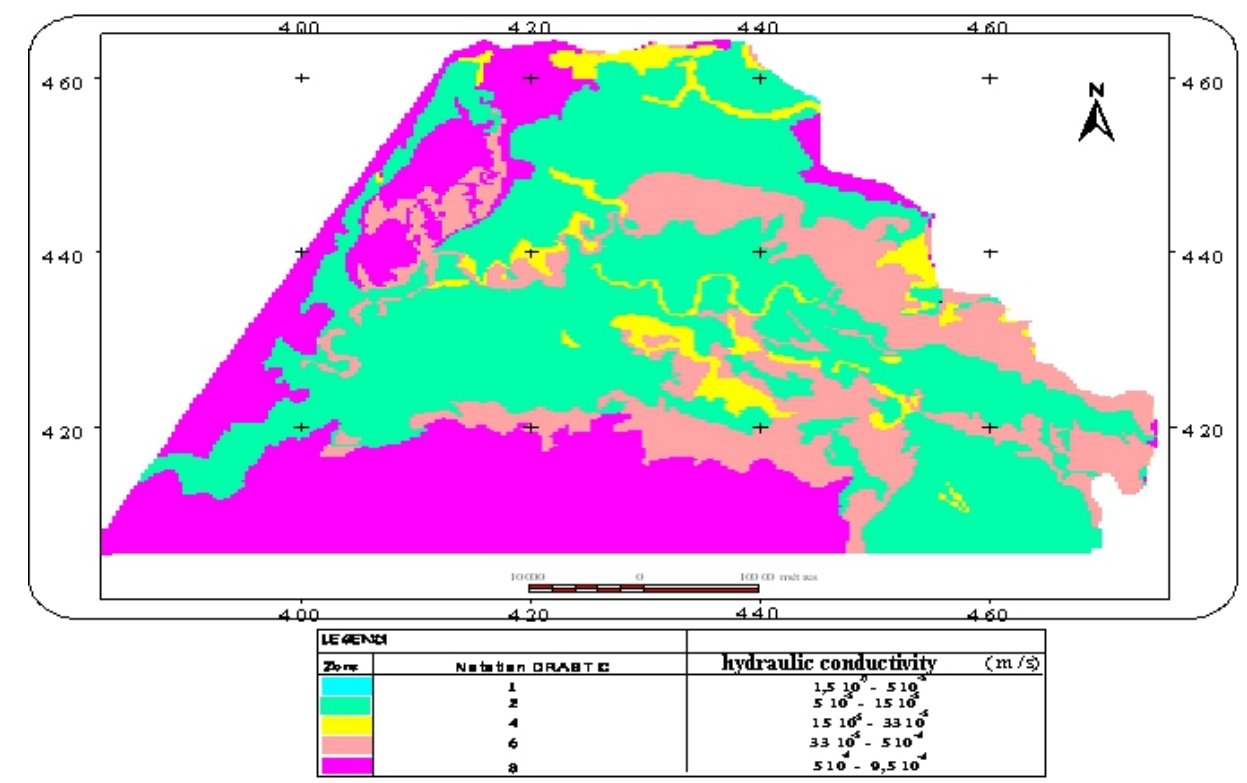

Fig.11 : Map of the permeability of Gharb's aquifer - DRASTIC NOTATION -

\section{Elaboration and interpretation of vulnerability map}

The compilation of all maps and calculation of drastic hint of vulnerability permitted to draw a vulnerability map of waters. This map is useful for the identification at the risk of pollution of hydric resources in Gharb. So, the repartition values obtained from this calculated hint permits to distinguish five zones according to the importance of risk (Fig. 12).

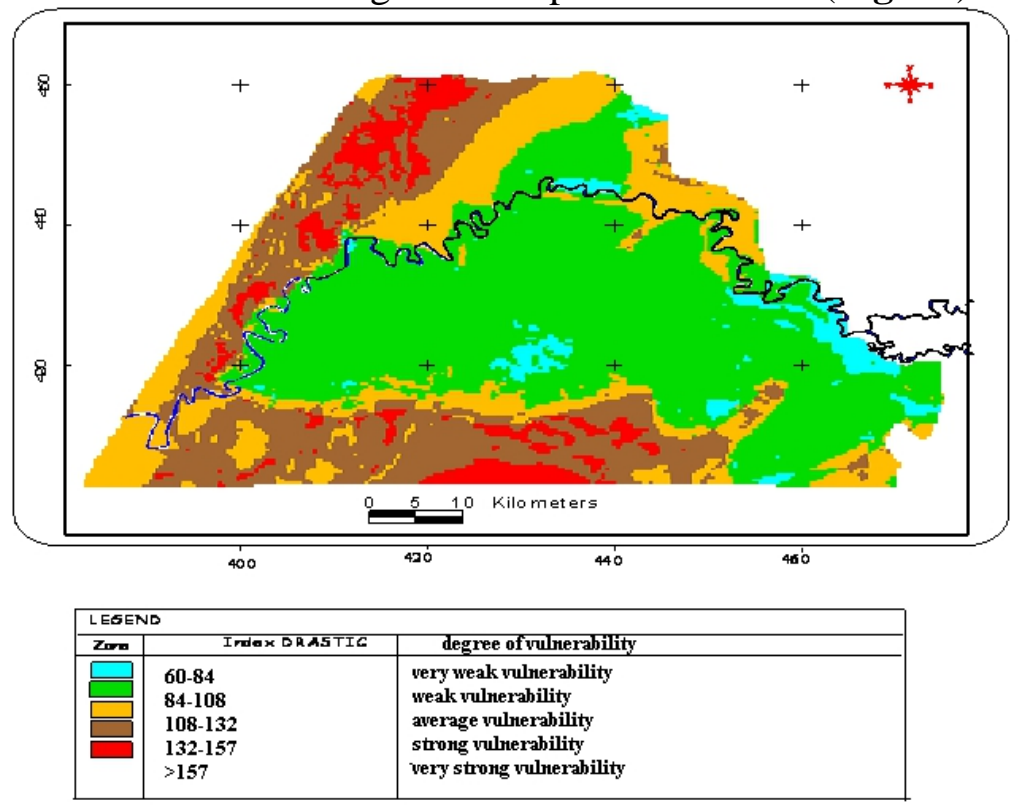

Fig.12: vulnerability map of Gharb`s aquifer - DRASTIC NOTATION - 


\section{The vulnerable zones and the very vulnerable ones.}

These zones are particularly localized in the south and in the coastal zones. However, we also find some very small vulnerable scattering in the center and in the east. This strong vulnerability coincides with the air which has a formation of good permeability, a little thick unsaturated zone, a plane topography, an important recharge which is variable from $15 \%$ to $20 \%$ and a little bit developed soil.

\section{The zones with an average vulnerability.}

They cover an important part in the center and in the east of the plain with a lot of depressions in the coastal zone. This air which is averagely vulnerable is mostly unsaturated and of an average permeability in relation to the zone with a strong vulnerability in which the slopes are very weak.

\section{The zones with weak and very weak vulnerability}

They are concentrated in the center of the plain where the soil and the unsaturated zone are very developed and the permeability is very weak.

\section{Repartition map of nitrate}

The first testing of this vulnerability can be done in comparison to repartition map of nitrate in the waters of Gharb's aquifer. The spacial repartition of the concentration in nitrate in the underground waters of Gharb shows that the superior contents in the moroccan norms of potability, which are $50 \mathrm{mg} / \mathrm{l}$ are revealed in the coastal zone as vulnerable (Fig. 13).

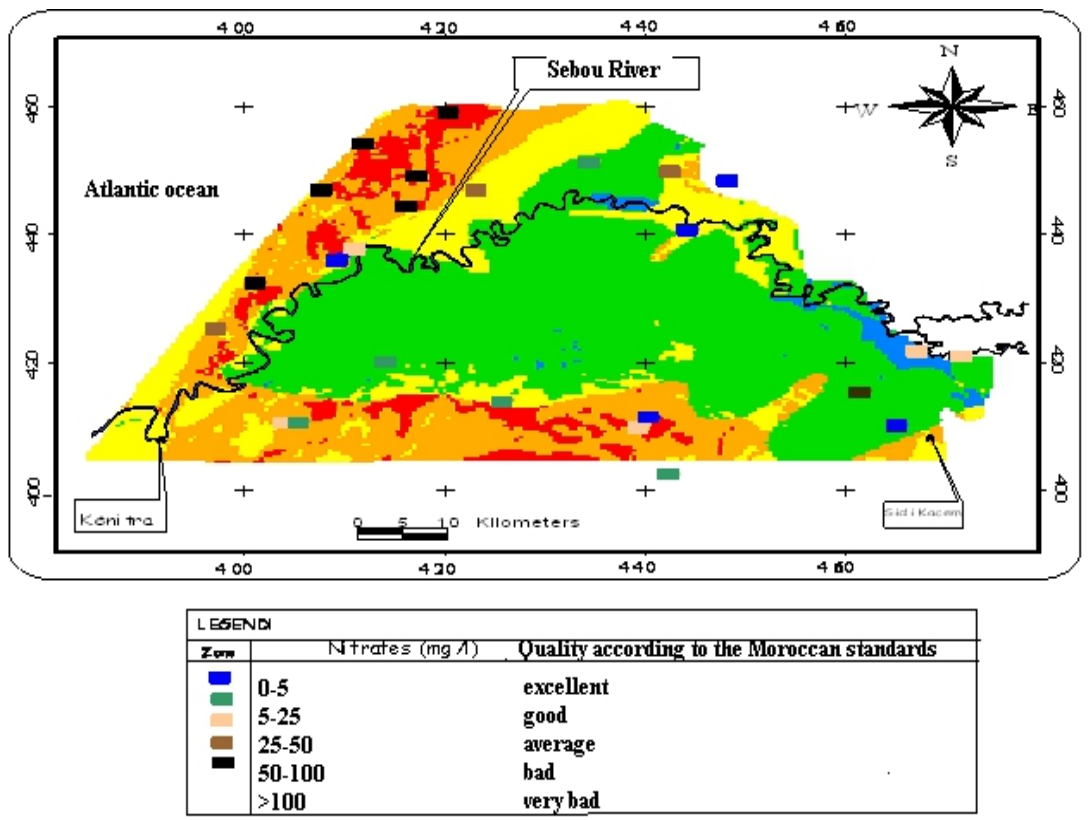

Fig.13: repartition map of nitrates in the underground waters of Gharb. 
This zone is emphasized as an intensive agricultural area, and therefore an excessive use of fertilizers and pesticides, constituting a danger to be managed by good agricultural practices which respect the recommended well-dosed nutritious needs. The profitability of the production mustn't take precedence over the human health.

\section{Conclusion}

The important resources of water of Gharb plain are in certain cases vulnerable to pollutions of the surface of the whole nature due to human activities. The vulnerability map of Gharb is simply a useful tool. It presents useful information territory management, taking decisions for water protection and initial diagnosis of the impact of accidental contamination. The vulnerability of the deep aquifer in Gharb, evaluated by means of Drastic method, is high in the coastal zones and in the south. The center of the basin presents a developed soil and impermeable, thick unsaturated zone. Its vulnerability is medium and weak. The zones in risk coincide with the air which has an intensive agricultural value and a rapid, brural peri-urban population which does not keep up with the real economic growth. The refore, it is dangerous for the quality of underground water. All in all, the evaluation of the Gharb plain and taking into consideration the vulnerability of water resources is a prerequisite to achieve sustainable development.

\section{References:}

1. Aller L., Bennet T., Lehr J.H., Petty R.J., and Hackett G. (1985). DRASTIC : a standardized system for evaluating ground water pollution potential using hydrogeologic settings.U.S. Environmental Protection Agency, EPA/600/2- 85-036, 455p.

2. Aberkan, M, (1989). Studies of the quaternary formations of the margins of the basin of Gharb (Morocco, North-West). Doctorate of state University of Bordeaux 1, n964, 290p.

3. Cirac, P, (1987). The south-west basin with the superior Neocene. Evolution of sedimentary dynamics and paleogeography during a phase of filling. Mem. Inst. Geol. Basin of Aquitaine, University of Bordeaux 1, $\mathrm{n}^{\circ}$ 21, $287 \mathrm{p}$.

4. Combe, M, (1975). The basin of Rharb-Mamora and small septrional basins of the wadis Dradère and Soueire. Water resources of Morocco. Plains and basins of Atlantic Morocco, Tome2, 454p.

5. Combe, M, (1969). Hydrogeologic cards of the plain of Rharb to the 1/100000. Notes and mem. Serv. Geol., Maroc, $n^{\circ} 221$ bis, 39 p. 
6. DRPE, 1996. Study of the aquiferous system of Gharb. Rapport of the direction of research and planning of water in Morocco, 67p.

7. DGH, 1999. Study of the system of royalty of pollution waters in the basin of Sebou. New report of the head office of hydraulics in Morocco, 80p

8. El mahmouhi, N, 2004. Water resources underground of the plain of Gharb : Hydrogeochemistry and vulnerability. Thesis of national doctorate. University Mohammed Morocco V- Rabat Morocco, $\mathrm{n}^{\circ} 2197,205 \mathrm{p}$

9. Arthurton, R. S., Kremeer, H. H., Odada, Salomons, E. W. \& Marshall-Crossland, J. I. (2002) African Basins. LOICZ Global Change Assessment and Sythesis of River Catchment-Coastal Sea Interaction and Human Dimensions. LOICZ Reports and Studies no. 25. The Netherlands.

10. Benaabidate, L. (2000) Characterization of the catchment area of Sebou : hydrogeology, quality of water and geochemistry of the thermal sources. Thesis be-Sc. F.S.T. Fès, Morocco.

11. Fauger J.C. 1978. Riffian south wrinkles. Sedimentary and structural evolution of atlantico-mesogeen basin of Africain margin $\mathrm{Ph}$. $\mathrm{D}$. thesis of state es-sciences. University of Bordeaux I.285p.

12. Flinch F.J. 1993. Tectonic evolution of the Gibraltar Arc. Ph. D. thesis, Rice University, 366p.

13. Lajat D., Biju-Duval B., Gonnard R., Letouzey J. et Winnock E. 1975. Prolongement dans 1'Atlantique de la partie externe de l'arc béticorifain. Bull. Soc. Geol. France, (7), XVII, N4. p. 481-485.

14. Michard, A, 1976. Moroccan geological elements, Notes and Mem. Serv. Geol. Morocco, Rabat, $\mathrm{n}^{\circ}$ 252, $408 \mathrm{p}$.

15. ORMVAG, 1998. ORMVAG report (Regional Office of Agriculture development in Gharb), $30 \mathrm{p}$.

16. RGPH, 1994. General census of population and habitat. Internal report 1994.

17. Surter, G, 1965. Regio of moyen Ouerrha (Rif, Morocco), preliminary study in stratigraphy and tectonics Notes Ser. Geol. Morocco, 24, 183, pp 7-17.

18. El Wartiti, M., Bahaj, T., El Mahmouhi, N., El Ghannouchi, A. \& Caboi, R. (2007) Contribution to a geochemical study of groundwater of the Gharb aquifer, Morocco. WRI 12, Chine, 1661-1664.Koukal, 
B., Dominika, J., Vignatia, D., Arpagausa, P., Santiago, S., Ouddane, B. \& Benaabidatee, L. (2004) Assessment of water quality and toxicity of polluted Rivers Fez and Sebou in the region of Fez (Morocco). Environmental Pollution 131 (2004) 163 to 172 